\title{
Methane emissions from the mines belonging to the Hunedoara Energy Complex
}

\author{
Emeric Chiuzan*, Razvan Dragoescu, Nicolae Ianc, Adrian Matei, and Alexandru Camarasescu \\ National Institute for Research and Development in Mine Safety and Protection to Explosion \\ INSEMEX Petrosani, 32-34 G-ral Vasile Milea Street, Petrosani 332047, Romania
}

\begin{abstract}
Methane emitted by the hard coal mines in operation in the Jiu Valley coalfield is under study in order to find out the most suitable solutions that increase occupational health and safety and at last, but not in the least, to capitalize the power generating potential of it. From the point of view of occupational safety, methane displays the highest risk because it can give birth to an explosive mixture with the air and the coal dust. Methane discharges into the outer atmosphere have a negative impact, increasing the greenhouse effect, with serious consequences over the parameters of the climate. This paper focuses on the use of mine gas in three important stages: solutions for the use of methane discharged by central degassing stations for power generating purposes; development of the network for the drainage of gases and increasing the volume of recovered methane; solutions for the use of $\mathrm{CH} 4$ from the general ventilation.
\end{abstract}

\section{Introduction}

The extractive industry, in particular, pollutes the air, water and soil through its activities.

This paper presents certain aspects related to pollution with the methane discharged by the main ventilation stations at the hard coal mines in the Jiu Valley.

The Hunedoara Energy Complex extracts coal from the Jiu Valley through 4 mining units. The amount of coal extracted in 2019 was approx. 410,000 tons.

The amount of methane discharged unit the air by these stations can reach hundreds of thousand of cubic meters/day at a concentration under $1 \%$ vol. Methane represents an important factor in the global heating process; it has a green house effect 21 times higher than carbon dioxide which can adversely influence the world clime.

This paper presents the method used to discharge methane into the surrounding atmosphere, the amounts and concentrations, methane capitalization and proposals for future uses of methane through unconventional means.

\section{Description of the Jiu Valley coalfield}

The Jiu Valley coalfield is the most important hard coalfield in Romania.

*Corresponding author: emeric.chiuzan@insemex.ro 
Due to its geological structural, it displays the most complex mining issues.

At present, there are only 4 (of which 2 are included in the closure program) active mines of 15 (during the " $90 \mathrm{~s}$ ) .

On the whole, Petrosani depression is an asymmetrical synclinal, orientated ENEWSW. The Northern side displays variable inclines between $25^{\circ}$ and $40^{\circ}$ and the Southern side between $10^{\circ}$ and $35^{\circ}$.

The disjunctive tectonic elements are represented by system of transverse and longitudinal faults of different extensions and sizes.

The hard coals extracted from the Eastern side are of the power-generating type and those extracted from the Western side are of the coking type.

Due to a large variation of forms, thickness, inclines and extension of hard coal beds, as well to the physical and mechanical features of the surrounding rocks, there are different mining methods[1]:

- The mining for small and average coal bed thickness (the mining takes places all through the coal bed thickness);

- Mining for thick coal beds (the coal bed is first divided into slices)

At the end of 2019, the gross production from the mines in the Jiu Valley, was about less than 500.00 million tons (table no. 1). In the current year a decrease in production is expected due to the restriction of operating areas and staff restructuring.

Table 1. Mines production in the Jiu Valley.

\begin{tabular}{|c|c|}
\hline MINING UNIT & $\begin{array}{c}\text { PRODUCTION } \\
\text { (tonnes/year) }\end{array}$ \\
\hline LONEA Mine & 35.536 \\
\hline LIVEZENI Mine & 108.419 \\
\hline VULCAN Mine & 145.816 \\
\hline PAROSENI Mine & - \\
\hline LUPENI Mine & 120.992 \\
\hline URICANI Mine & - \\
\hline TOTAL & 410.763 \\
\hline
\end{tabular}

At the end of 2019, the Paroseni and Uricani mines completed the closure process, being completely closed.

\section{Methane in the Jiu Valley coal mines}

Methane associated to the coal deposits formed at the same time with these deposits, as a results of the anaerobic carbonification of the vegetable matters settled can be found both in free and bonded state inside the coal beds and inside the surrounded rocks: it can be free inside voids (pores, fissures) and bonded under two forms (adsorbed, chemo-sorbed)[6].

If we speak about the capitalization of methane come from the coal deposits, the most valuable is free methane and, only particularly, absorbed methane that can be released after changing tensions in side the rock massif, as a result of mining operations.

Methane in the underground atmosphere is a risk factor for a safe mining of coal deposits; subsequently, there have been implemented safety measures that provide a controlled catching and discharge of methane into the open air.

Nevertheless, methane released into the open air displays adverse effects over the atmosphere: it destroys the ozone layer and accelerates the greenhouse effect.

At the same time, the methane gas released into the atmosphere at the same time as coal mining can be used by mining operators as a primary energy resource to cover their own energy needs, or it can be used for commercial purposes[3]. 
The table below (table no. 2) contains the amount of methane gas discharged into atmosphere, through the ventilation systems of the mines in the Jiu Valley during 2019[5].

Table 2. The amount of gas released into the atmosphere.

\begin{tabular}{|c|c|}
\hline MINING UNIT & $\begin{array}{c}\text { Methane Discharged } \\
\text { (tonnes/year) }\end{array}$ \\
\hline LONEA Mine & 432,83 \\
\hline LIVEZENI Mine & $1.025,387$ \\
\hline VULCAN Mine & 89,465 \\
\hline PAROSENI Mine & 783,28 \\
\hline LUPENI Mine & 778,63 \\
\hline URICANI Mine & $1.589,30$ \\
\hline TOTAL & $4.698,542$ \\
\hline
\end{tabular}

It is required to developed certain studies in order to find the appropriate solutions for recovery and utilization of the important quantities of methane, witch are currently released in the environment.

\section{Degassing}

In order to settle the suitability of more degassing, one should make a detailed analysis of the factors that influence methane emissions and of the ventilation factor; there shall be also fore casted gas emissions and it is also necessary to know clearly coal deposits, the mining dynamics and to determine the qualitative and the quantitative factors[2].

For the conditions specific to the Jiu Valley, these criteria comprise:

- the dilution capacity of methane by ventilation means at maximum velocities so as not to impair comfort in underground and to stir up the coal dust;

- methane concentrations at the point where the stope crosses the headway or inside goofs and limiting the coal output in relation to the maximum admitted concentrations;

- preventing gasodynamic phenomena during cull-de sac coal mining.

Coal beds and the surrounding rocks shall be degassed during:

a. cul-de-sac coal mining when:

- the absolute methane flow rate that is emitted by the mine working whose mining length exceeds $150 \mathrm{~m}$, is higher than $3 \mathrm{~m}^{3} / \mathrm{min}$;

- the absolute methane flow rate that is emitted by the mine working nearby faults, within $10 \mathrm{~m}$, is highs than $1,5 \mathrm{~m}^{3} / \mathrm{min}$;

- the absolute methane flow rate that is emitted by the chamber is higher than $3 \mathrm{~m}^{3} / \mathrm{min}$.

b. stopes mining when :

- the absolute methane flow rate emitted by coal beds exceeds $15 \mathrm{~m}^{3} / \mathrm{t}$ or,

- the absolute methane flow rate emitted by the stope in operation exceeds $6 \mathrm{~m}^{3} / \mathrm{min}$.

From technical point of view, degassing is dutiable when the dilution of methane emissions under the values stipulated by the standards in force cannot be accomplished by ventilation means. It is considered that a methane flow rate higher than $15 \mathrm{~m}^{3} / \mathrm{t}$ requires a degassing of coal beds[4].

At present, the Jiu Valley coalfield sees two types of degassing systems:

- local degassing;

- centralized degassing.

The local degassing is being performed with the help of 5DIV and 8DIV ejectors, with nominal flow rates between 10 and $18 \mathrm{~m}^{3} / \mathrm{min}$ with nominal depression between 300 and $350 \mathrm{~mm} \mathrm{Hg}$ and compressed air consumption between 4 and $10 \mathrm{~m}^{3} / \mathrm{min}$. 
This equipment is located in underground and it can be moved from one location and it another according to the needs.

At present, the local degassing is applied only to the Livezeni mine

Centralized degassing systems are located at the surface of mines and are equipped with four vacuum pumps groups for the gas suction. This Polish equipment display a flow rate of $\mathrm{Q}=25 \mathrm{~m}^{3} / \mathrm{min}$, a maximum suction depression of $\mathrm{H}=4,000 \mathrm{~mm} \mathrm{H}_{2} \mathrm{O}$, discharge pressure $\mathrm{P}=3000 \mathrm{~mm} \mathrm{H}_{2} \mathrm{O}$ and the power of motors $\mathrm{N}=75 \mathrm{Kw}$.

Central degassing is applied to a number of three mines, namely, Livezeni, Vulcan, and Lupeni.

Methane catching is performed through holes drilled in underground and from goafs.

The areas subjected to degassing have been determined in relation to the above-said criteria, based on a project developed by the mine and approved by INCD INSEMEX Petrosani.

The drill holes used during the degassing process are made based on the same project that comprises the number of locations, the amount of drill holes per location, their diameter, length, direction and inclination.

The drill holes shall be lined and sealed along 6-12 $\mathrm{m}$ and equipped with valve and connectors for measurement and control purposes.

\section{Capitalization of methane in the Jiu Valley mines}

Jiu Valley basin has important reserves of CBM, located in the coal seams and neighboring rocks. The geological parameters of this area are higher, in certain aspects, than those of certain coal areas (Ration Basin - Colorado, USA, Germany) where the exploration and extraction of CBM is performed with good or very good results.

From economic point of view, it is proved that recovery methane the coal mines represents a profitable activity both for mining company and for a possible investitors. The volume of methane located in the bituminous coal deposit I Jiu Valley is very large and can provide large capacities for recovering this gas. In the same time, the market for this product exists already in Jiu Valley, consisting in industrial and individual consumer; very small part of population and non significant of industrial consumers have a connection to the methane network.

Methane in the coal deposits can be captured through drill holes and then it is sent towards the surface to the central degassing station; subsequently, this methane can be used for different purposes.

Prior to sending the gas to the user, water is removed from methane.

There has to be a continuous flow of methane from the coal beds in order to get a reliable commercially production.

In a calculation of methane obtained at a central degassing station, with an average flow rate of $4 \mathrm{~m} 3 / \mathrm{min}$, at an average concentration of $60 \%$ it can be used at:

- to product house hot water necessary for more than 4,000 person, or;

- to heat up a surface of around $1,500 \mathrm{~m}^{2}$ inhabited area;

- to heat up a small district of dwelling places ( $750 \mathrm{~m}^{2}$ inhabited area) of more than 200 person.

Consequently, if on capitalizes methane come from a degassing station at an average flow rate of $4 \mathrm{~m}^{3} / \mathrm{min}$ and an average concentration of $60 \%$, one shall get a calorific flow rate of $32,700,000 \mathrm{Kcal} /$ day or $1,362 \mathrm{Kcal} / \mathrm{h}$.

This calorific flow rate used a boiler with calorific efficiency of $70 \%$ can deliver $460 \mathrm{~m}^{3}$ of water/day heated at $55{ }^{0} \mathrm{C}$. 
In the Table 3 shows the amount of methane gas captured at the main stations degassing from the Jiu Valley mines and the amount of methane recovered for energy production during 2019.

Table 3. Average of Methane Flow.

\begin{tabular}{|c|c|c|}
\hline \multirow{2}{*}{ MINING UNIT } & \multicolumn{2}{|c|}{ Amount of methane (tons/year) } \\
\cline { 2 - 3 } & Extracted by degassing & Recovered for energy production \\
\hline LUPENI Mine & 60,314 & 60,314 \\
\hline PAROSENI Mine & $1.016,68$ & - \\
\hline VULCAN Mine & 386,43 & 386,43 \\
\hline LIVEZENI Mine & 143,444 & - \\
\hline TOTAL & $1.606,86$ & 446,774 \\
\hline
\end{tabular}

At present, the methane extracted using the central degassing installations is used as follows[5]:

- The E.M. Lupeni - in the thermal power plant inside the mine equipped with two boilers for hot water of $15 \mathrm{Gcal} / \mathrm{h}$. We mention that in the warm seasons the consumption of methane gas was between 2.9-4.3 $\mathrm{m} 3$ / $\mathrm{min}$, while in winter it reaches values of 7.6-9.4 $\mathrm{m} 3 / \mathrm{min}$, there are also situations when consumption needs they exceeded the amount of methane obtained through their own degassing station.

- The E.M. Vulcan methane has a flow of about $1.25 \mathrm{~m} 3 / \mathrm{min}$ and has two domestic water heating boilers in the miners' baths.

- The E.M. Livezeni is the problem with the capitalization of methane in the sense that the degassing station is at a great distance from the mine. The only possibility would be to use methane gas at the nearby lumber mill, to produce domestic hot water and hot air needed for the technological flow.

\section{Conclusions}

- The production of coal in 2019 was slightly over 410.000 tons.

- At the level of the Jiu Valley coal basin, over 9 tons of methane are evacuated daily in the atmosphere.

- Methane evacuation takes place at the main ventilation stations and at the central degassing stations that do not use it.

- The total amount of methane extracted by the central degassing stations is $1.606,86$ tons/year, of which only $27 \%$ are recovered.

- The amount of methane recovered at the Lupeni mine is approx. $7 \%$ and about $18 \%$ at the Vulcan mine, from the total methane resulting from the exploitation.

The classic use of methane is burning in thermal power station (we speak here about methane released by central degassing station) and catalytic burning of methane at concentration below 1\% come from main ventilation stations At present catalytic burning plants are quite expensive so they are not used in Romania.

Given that the Hunedoara Energy Complex is undergoing a major restructuring process, it is soon not expected to purchase methane combustion plants of less than $1 \%$ from the main ventilation stations.

\section{References}

1. D. Cioclea, L. Jurca, E. Chiuzan "Risk assessment and elaboration of the protection system a environmental emissions explosive and toxic in areas mining with me subjected to the process closing" 
2. E.Chiuzan, D . Cioclea,D. Tamas, „Reducing methane emissions main ventilation stations at mines in the Jiu Valley through perfecting the methods of recovery and verification of it from the coal seams"

3. E Chiuzan "Mine Degassing"

4. E. Chiuzan ,Methane in Coal Mines”

5. E. Chiuzan „Annual report to the MINISTRY OF THE ENVIRONMENT, National Agency for Environmental Protection, National System for Estimating Greenhouse Gas Emissions (SNEEGES) ',

6. I.Gherghe, D. Cioclea, E. Chiuzan, F. Radoi, V. Pasculescu Influence of the natural draft's depression upon mining ventilation networks The $6^{\text {th }}$ BALKAN MINING CONGRESS,20 - 23 September 2015 PETROSANI - ROMANIA 